\title{
IN VESTIGATION OF DISPOSAL OF LIQUID WASTES \\ FROM OLEFIN PRODUCTION BY SODIUM HYPOCHLORITE SOLUTIONS
}

\author{
Zenoviy Znak ${ }^{1}{ }^{*}$, Olha Zin ${ }^{1}$
}

https://doi.org/10.23939/chcht11.04.517

\begin{abstract}
It has been studied an effect of ratio between arene and alkene organic compounds, as components of olefin production wastewaters, and sodium hypochlorite, as liquid waste of caustic soda and chlorine synthesis, on their interaction. The organics total content was expressed by a value of chemical oxygen demand. A fundamental possibility of the mutual neutralization was confirmed. Use of a cavitation field significantly reduces duration of the process and the ratio between sodium hypochlorite and organic compounds. The implementation of this process under adiabatic conditions allows to accelerate the neutralization due to the environment temperature increase caused by cavitation. It was found from calculated process kinetic parameters that magnetostriction radiator causes cavitation excitation in the diffusion area.
\end{abstract}

Keywords: wastewater neutralization, wastewater treatment, sodium hypochlorite, cavitation, alkene, arene, destruction.

\section{Introduction}

State of natural waters and aquatic ecosystems essentially depends on the composition of liquid wastes and wastewaters that fall into the water basins. This problem is very actual in Ukraine, because a considerable part of wastewaters flows down in natural basins insufficiently treated or even untreated. This is caused by insufficient funding for treatment of wastewaters and lack of effective technologies of their conditioning. This especially relates to wastewaters with high organic compounds content which are characterized by low values of biological and chemical oxygen demands (BOD and COD respectively). If the $\mathrm{BOD}_{5}$ value is less than $80 \%$ of the COD, the biological treatment is ineffective.

Wastewaters generated in olefins technology which is based on pyrolysis of diesel fuel contain significant

\footnotetext{
${ }^{1}$ Lviv Polytechnic National University,

12, Bandery St., 79013 Lviv, Ukraine

znak_zo@ukr.net

(c) Znak Z., Zin O., 2017
}

amounts of organic compounds. Determination of the qualitative and quantitative composition of the liquid phase is not included in technological regulations of olefins production and treatment facilities, where these waters are directed for purification. The total content of organic compounds is expressed by $\mathrm{COD}, \mathrm{BOD}_{5}$ and $\mathrm{BOD}_{20}$ values of oxygen consumption, which reach 3500 , 1600 and $1780 \mathrm{mgO}_{2} / \mathrm{dm}^{3}$ respectively. Thus proportion of $\mathrm{BOD}_{5}$ does not exceed $46 \%$ of the COD, which leads to low efficiency purification by biological methods.

Our preliminary experiments, including spectrophotometric investigations, established that the main components of olefins production wastewaters are arene and alkene compounds at their molar ratio of 0.4:1. These compounds are sufficiently resistant to biological degradation, which causes low values of the $\mathrm{BOD}_{5} / \mathrm{COD}$ ratio.

The implementation of pretreatment using sorbents $[1,2]$, reagents, especially oxidants $[3,4]$ allows to achieve the required degree of purification, but greatly increases the cost of the process mainly due to the spending on reagents and regeneration of sorbents.

The use of liquid wastes of related industries containing oxidant - sodium and calcium hypochlorites was proposed for the removal of organic arene and alkene compounds in terms of implementation of modern concepts of designing of chemical-engineering systems. In particular, sodium hypochlorites are generated during the production of chlorine and caustic soda as well as in technology of colloidal silica and calcium hypochlorite in the production of magnesium by an electrochemical method. The content of hypochlorites in these solutions with $\mathrm{pH}$ of $10-13$ can be up to $40 \mathrm{~kg} / \mathrm{m}^{3}$.

Considering that, with the increase of $\mathrm{pH}$ oxidative properties of hypochlorite decrease, it can be expected that the oxidation of organic compounds can occur too slowly. Therefore one way to speed up the process is its implementation in a cavitation field [5-8]. It is known that degradation of organic compounds with the formation of intermediate radicals which may contribute to the intensification of hypochlorite oxidation takes place in the cavitation field. 
Purpose of the work is to study a possibility of treatment of olefins production wastewaters containing alkene and arene compounds by sodium hypochlorite and intensification of the process in the cavitation field.

\section{Experimental}

Averaged olefin production wastewaters (OPW) and sodium hypochlorite solutions (SHS) were used in the study. The COD value of olefin wastewaters was $3200 \mathrm{mgO}_{2} / \mathrm{dm}^{3}$ at $\mathrm{pH} 6.5-8.0 . \mathrm{NaClO}$ concentration in the solution was equal to $35.2 \mathrm{~g} / \mathrm{dm}^{3}$.

The study was performed in a thermostatted reactor with the volume of $0.25 \mathrm{dm}^{3}$ under intensive stirring, particularly in the cavitation field. The cavitation field was generated by ultrasonic magnetostrictive radiator Ultrasonic UD-20 with a radiation frequency of $22 \mathrm{kHz}$. Values of environment redox potential (ORP) were measured by universal ionomer EV-74 with an electrode system (platinum measuring electrode EVP-1 and silver chloride reference electrode EVL-1). Environment $\mathrm{pH}$ value was measured by $\mathrm{pH}$-meter of $\mathrm{pH}-150 \mathrm{M}$ type with combined electrode ESKL-08M1.

The COD value of the reaction environment was determined according to the standard procedure of ISO 6060: 2003.

Photometric studies of reaction environments were performed on two-bam spectrophotometer Specord M40 (UV-VIS) Carl Zeiss JENA (wavelength range 200-400 nm, quartz cuvette thickness $10 \mathrm{~mm}$ ) and photoelectric photometer KFK-3 (reference wavelength $380 \mathrm{~nm}$; quartz cuvette thickness $30 \mathrm{~mm}$ ). Distilled water was used as a control environment in both cases.

\section{Results and Discussion}

It was found by a spectrophotometric method that olefin production wastewaters mainly contain aromatics, including benzene, and linear unsaturated compounds. Thus, a fine structure of the absorption band in the longwave region of $230-269 \mathrm{~nm}$ with a maximum at $256 \mathrm{~nm}$, which is typical for benzene - benzene absorption band [9], is available on UV-spectrum of olefin production wastewaters (Fig. 1). Certain shift of the absorption band in the short-wave region can be explained by the fact that the object of the study was an aqueous solution, while indications are for a solution of benzene in hexane. The absorption region in the range of 310-390 nm testifies the presence of unsaturated compounds [10].

Investigation of organic compounds neutralization in OPW by $\mathrm{NaClO}$ solution was performed by a redox titration: SHS was added by portions to $50 \mathrm{~cm}^{3}$ of OPW.
Each subsequent portion was added only after achieving sustainable ORP value of the reaction medium which indicated the practically complete cessation of the process. Integrated content of organic compounds in OPW was expressed by $\mathrm{COD}$ value $\left(\mathrm{mol} \mathrm{O}_{2} / \mathrm{dm}^{3}\right)$ and $\mathrm{NaClO}-$ through the oxygen content in it $\left(\mathrm{mol} \mathrm{O}_{2} / \mathrm{dm}^{3}\right)$ for convenience of experimental results analysis. Therefore, the content of organic compounds in the reaction medium of certain volume was expressed through the appropriate number of moles of $\mathrm{O}_{2}-n\left(\mathrm{O}_{2, \mathrm{org}}\right)$, and the quantity for $\mathrm{NaClO}-n\left(\mathrm{O}_{2, \mathrm{NaClO}}\right)$.

The results indicate (Fig. 2) that organic compounds oxidation occurs due to the addition of $\mathrm{NaClO}$ solution to OWP. The dependence of the final stable ORP value on the organic compounds to $\mathrm{NaClO}$ ratio is similar to a typical curve of redox titration with a characteristic jump of potential at the point of equivalence, which corresponds to $n\left(\mathrm{O}_{2, \mathrm{NaClO}}\right): n\left(\mathrm{O}_{2, \mathrm{org}}\right)$ ratio $\approx 1.92 \mathrm{~mol} / \mathrm{mol}$.

Deep enough oxidation of organic compounds is confirmed by the determination of COD and spectrophotometric analysis. The COD value of the reaction medium is reduced to $120 \mathrm{mgO}_{2} / \mathrm{dm}^{3}$ which corresponds to $96.2 \%$ integral degree of organic compounds oxidation.

The intensity of OPW spectrum peak in the area of absorption of aromatic compounds is sharply reduced after addition of SHS and its fine structure is not detected. This means that oxidative destruction of aromatic compounds with subsequent oxidation of generated linear fragments occurs under the influence of $\mathrm{NaClO}$.

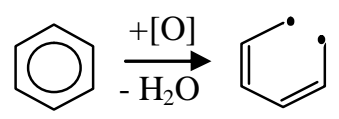

The intensity of the peak in the absorption region, which is typical for alkanes, is four times less due to the oxidative destruction [11] and partial oxidation of alkenes and their degradation products after addition of sodium hypochlorite excess to OPW.

Series of curves 1-5 and 6-10 (Fig. 3) were obtained by a spectroscopic study of the reaction medium with an interval of $15 \mathrm{~min}$ (duration of one spectrophotometric experiment was $5 \mathrm{~min}$ ).

The character of ORP change in time, for instance at the ratio $v\left(\mathrm{O}_{2, \mathrm{org}}\right): v\left(\mathrm{O}_{2, \mathrm{NaClO}}\right)=2$ (Fig. 4), indicates the progress of complicated parallel-sequential processes in the reaction system. The sharp increase in the ORP value for the first 3-4 min is due to the oxidation of organic compounds that remained after the addition of previous portions of $\mathrm{NaClO}$ solution. However monotonic change of ORP, expected in the case of deep oxidation of organic compounds, was not observed. The chaotic change of the system redox potential about $135 \mathrm{mV}$ was noted in the range of $20-70 \mathrm{~min}$. A change of the medium optical 
density is almost monotone and proportional to organic compounds content, which was identified in control experiment; the integral content of organic compounds is reduced. Final COD value of the solution is about $340 \mathrm{mgO}_{2} / \mathrm{dm}^{3}$. This means that the interaction between organic compounds and sodium hypochlorite occurs through the formation of numerous intermediates with different redox properties. Identification of these compounds has not been the subject of the research. The conclusion about the effectiveness of interaction between organic compounds and sodium hypochlorite was made basing on the final value of environment COD.

The theoretical ratio $n\left(\mathrm{O}_{2, \mathrm{NaClO}}\right): n\left(\mathrm{O}_{2, \mathrm{org}}\right)$, at which complete oxidation of organic compounds would be

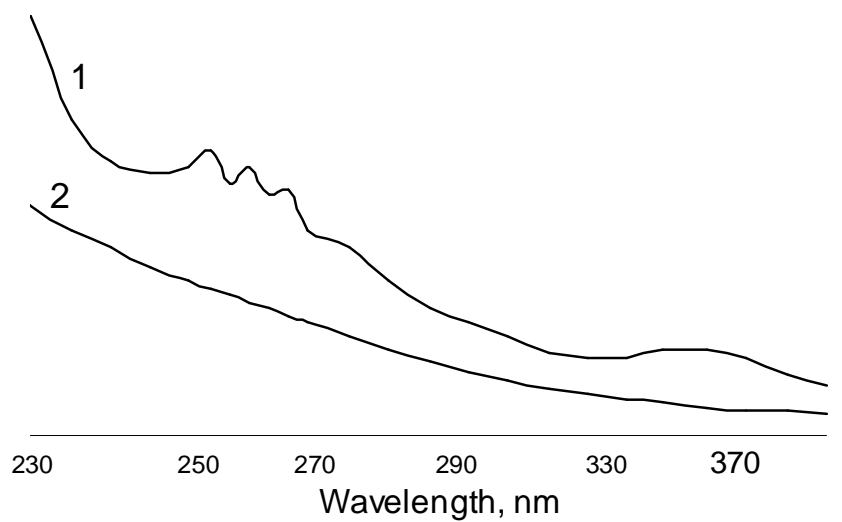

Fig. 1. UV - spectra: OPW (1) and OPW after addition of $\mathrm{NaClO}$ excess (2)

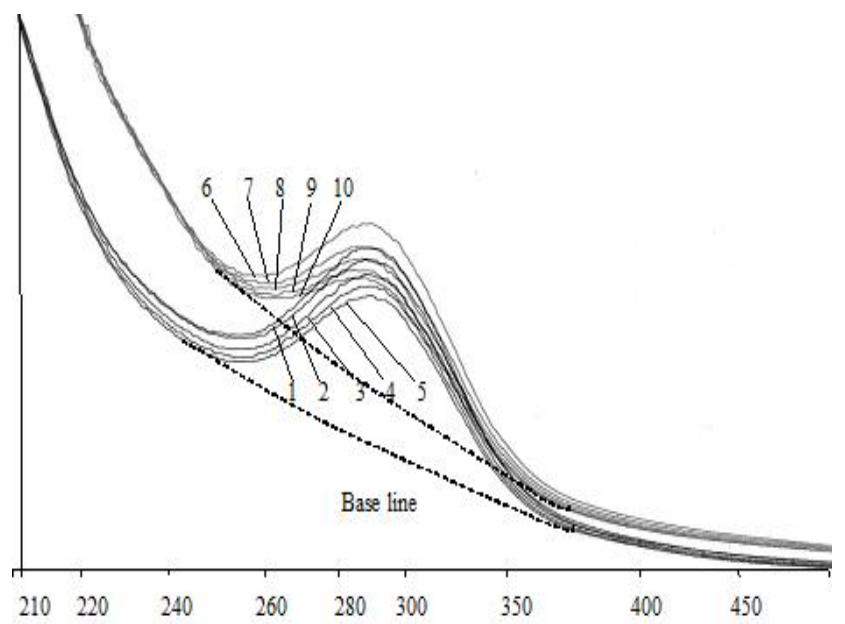

Wave length, $\mathrm{nm}$

Fig. 3. UV-Viz-spectra of reaction environments at mechanical mixing (1-5) and under ultrasonic radiation at $293 \mathrm{~K}(6-10)$. Process duration, min: 5 (1, 6); 10 (7); 15 (2); $20(8) ; 30(3,9) ; 40(10) ; 45(4) ; 60(5)$ achieved, is equal to $1.51 \mathrm{~mol} / \mathrm{mol}$ and was calculated using COD value of OPW. Excess sodium hypochlorite at the time of achieving equivalence point (Fig. 2) is about $30 \%$, taking into account the integral degree of conversion of organic compounds. This can be explained by relatively low selectivity of the process for sodium hypochlorite because of its decomposition with the release of atomic oxygen:

$$
\mathrm{NaClO}=\mathrm{NaCl}+\mathrm{O}
$$

which further converts into a molecular oxygen. It is clear that the molecular oxygen has much less pronounced oxidizing properties $\left(E^{0}\left(\mathrm{O}_{2} / \mathrm{OH}^{-}\right)=0.40 \mathrm{~V}\right)$ than sodium hypochlorite $\left(E^{0}\left(\mathrm{ClO}^{-} / \mathrm{Cl}^{-}\right)=1.49 \mathrm{~V}\right)$ and atomic oxygen.

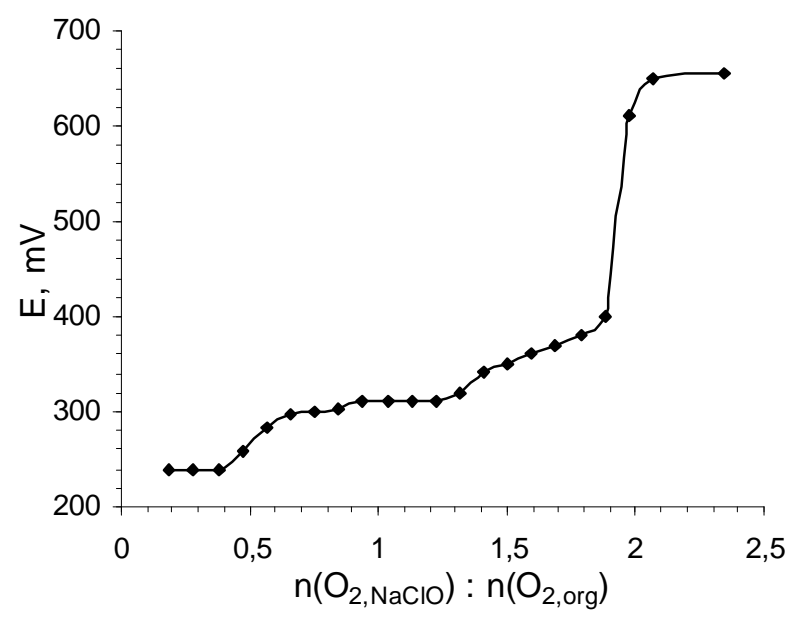

Fig. 2. ORP value ratio vs. $n\left(\mathrm{O}_{2, \mathrm{org}}\right): n\left(\mathrm{O}_{2, \mathrm{NaClO}}\right)$

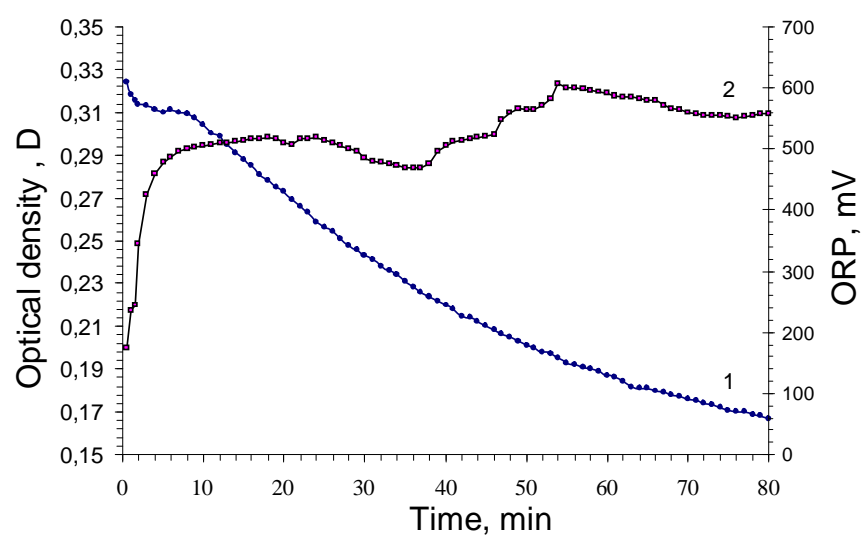

Fig. 4. Time dependence of optical density (1) and ORP (2) of the reaction medium; $v(\mathrm{O} 2, \mathrm{org}): v\left(\mathrm{O}_{2, \mathrm{NaClO}}\right)=2$ 
Thus, it was found that the organic compounds in OPW can be effectively oxidized using sodium hypochlorite, which is contained in the liquid wastes of related production. In other words it is confirmed that there is a principal opportunity to neutralize olefin production wastewaters by using the wastewaters from chlorine and caustic soda production.

It was found during the study that the duration of interaction between organic compounds $\mathrm{OPW}$ and $\mathrm{NaClO}$ depends on $n\left(\mathrm{O}_{2, \mathrm{NaClO}}\right): n\left(\mathrm{O}_{2, \mathrm{org}}\right)$ ratio. Duration of the interaction between organic compounds with $\mathrm{NaClO}$, determined by time to achieve sustainable ORP value, increases from 4 to $90 \mathrm{~min}$ with rising of this ratio from 0.19 to $0.8-1.2 \mathrm{~mol} / \mathrm{mol}$, in other words with a gradual increase of sodium hypochlorite concentration in the reaction medium. Probably, low content of $\mathrm{NaClO}$ quickly expends at a significant excess of organic compounds stable ORP value of $240 \mathrm{mV}$ is reached quickly. The concentration of oxidant and reducing agents rapidly decreases with the increase of ORP content, i.e. with the decrease of $n\left(\mathrm{O}_{2, \mathrm{NaClO}}\right): n\left(\mathrm{O}_{2, \mathrm{org}}\right)$ ratio. The result is the reduction of reaction rate, causing longer duration of the process. The process duration is reduced to $24 \mathrm{~min}$ with increase of $\mathrm{NaClO}$ concentration (by reduction of $n\left(\mathrm{O}_{2, \mathrm{NaClO}}\right): n\left(\mathrm{O}_{2, \text { org }}\right)$ ratio to $\left.2.33 \mathrm{~mol} / \mathrm{mol}\right)$ and $\approx 650 \mathrm{mV}$ of ORP value is achieved.

Taking into account a daily volume of liquid wastes and their content, the consumption of SHS will be sufficient to disposal only $10-20 \%$ of OPW even at $100 \%$ selectivity of the process concerning $\mathrm{NaClO}$. Therefore, further investigations were devoted to intensification of OPW disposal process using SHS by the cavitation method. The research was conducted under isothermal conditions and temperature of $293 \pm 1 \mathrm{~K}$.

$\mathrm{NaClO}$ solution was added to OPW by portions after achievement of stable ORP value of the system in the case of cavitation field excitation. It was established that potential jump within $350-600 \mathrm{mV}$, which corresponds to the equivalence point, can be observed at $n\left(\mathrm{O}_{2, \mathrm{NaClO}}\right): n\left(\mathrm{O}_{2, \text { org }}\right) \approx 0.64 \mathrm{~mol} / \mathrm{mol}$. This is 2.36 and 3.0 times less in comparison with the ratio of calculated theoretically and experimentally determined, respectively. Herewith, duration of the interaction of organic compounds with $\mathrm{NaClO}$ in the cavitation field is much less (Fig. 5). Thus, the rate of interaction in the cavitation field is 6.6 times higher in the equivalence point for $n\left(\mathrm{O}_{2, \mathrm{NaClO}}\right): n\left(\mathrm{O}_{2, \text { org }}\right) \approx 0.64 \mathrm{~mol} / \mathrm{mol}$.

The sharp decrease of $n\left(\mathrm{O}_{2}, \mathrm{NaClO}\right): n\left(\mathrm{O}_{2, \text { org }}\right)$ ratio, in other words, the $\mathrm{NaClO}$ quantity, which is necessary for the oxidation of organic compounds in OPW, can be explained by a number of processes during cavitation. Processes which occur in the cavitation field can be attributed to primary ones, namely destruction of organic compounds, water sonolysis, decomposition of $\mathrm{NaClO}$.

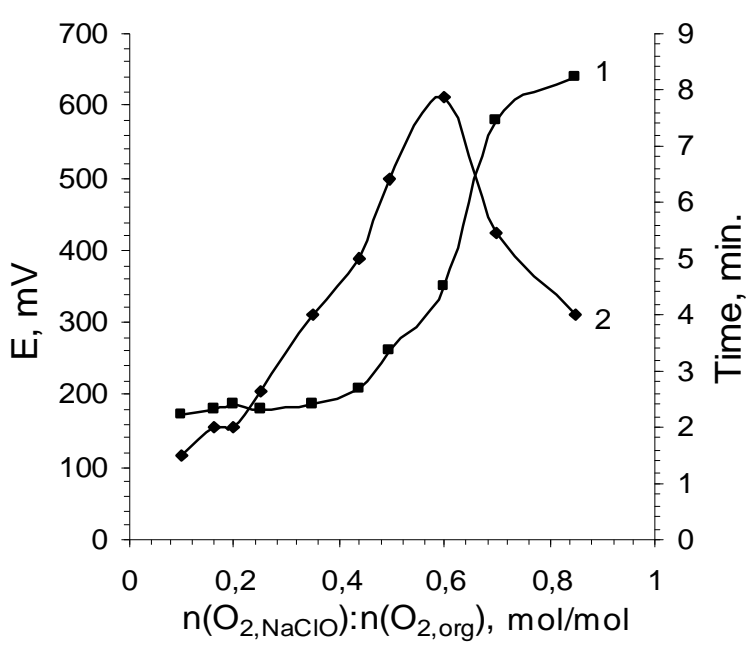

Fig. 5. Dependence of ORP value (1) and duration of the interaction of organic compounds with $\mathrm{NaClO}$ (2) on $n\left(\mathrm{O}_{2, \mathrm{NaClO}}\right): n\left(\mathrm{O}_{2 \text {, org }}\right)$ ratio in the cavitation field at ultrasound radiation intensity of $8.2 \cdot 10^{-2} \mathrm{~W} \cdot \mathrm{cm}^{-3}$

Part of organic compounds is destructed with the formation of the corresponding fragments during cavitation. The research results of OPW cavitation treatment under isothermal conditions confirm this. ORP value of environment is reduced by $100-120 \mathrm{mV}$ due to the increased molar concentration (activity) of organic compounds within the first 10-15 min. These organic compounds or rather their fragments are characterized by reduction properties and decrease of $\lg \left(a_{\mathrm{OX}} / a_{\mathrm{Red}}\right)$ value in Nernst equation. Herewith, COD value of the environment remains almost constant because the integral numbers of carbon and hydrogen do not change. Even the partial defragmentation of organic compounds leads to the formation of the corresponding organic radicals.

Sonolysis of water with the formation of numerous compounds of oxidative nature, in particular atomic oxygen, hydrogen peroxide, singlet oxygen, ozone, etc. [12] occurs simultaneously with the destruction of organic compounds. $\mathrm{NaClO}$ decomposition with the formation of atomic oxygen also takes place. Generated oxygen containing compounds with oxidizing properties initially cause oxidative degradation of organic compounds as evidenced by a further decrease of ORP value of the environment and a slight decrease of COD value during the next 5-7 min. Later, deep oxidation of organic compounds and their fragments to stable end products $\left(\mathrm{CO}_{2}\right.$ and $\left.\mathrm{H}_{2} \mathrm{O}\right)$ occurs, causing a decrease of $\mathrm{COD}$ value to $120-140 \mathrm{mgO}_{2} / \mathrm{dm}^{3}$. Possibly, a decrease of sodium hypochlorite consumption for oxidation of organic compounds during cavitation process is caused by participation of oxidants formed owing to water sonolysis in this process. Moreover, fragments of radical nature are formed due to the destruction of organic compounds, 
which causes substantial acceleration of oxidation rate and increase of action selectivity of formed intermediate oxidants. The rate of organic compounds conversion under the influence of ultrasound radiation, equal to $0.51 \cdot 10^{4} \mathrm{~mol} /\left(\mathrm{dm}^{3} \cdot \mathrm{s}\right)$, is 4.6 times higher than for ideal mixing regime.

The course of the process for radical mechanism is confirmed by the low activation energy of interaction of organic compounds with sodium hypochlorite and the reaction order. The activation energy is just $27.5 \pm 0.5 \mathrm{~kJ} / \mathrm{mol}$, and the order of the reaction is close to one $(n=0.95-1.16)$ for the intensity of ultrasonic radiation of $8.2 \cdot 10^{-2} \mathrm{~W} \cdot \mathrm{cm}^{-3}$.

Obtained data clearly demonstrate the effectiveness of the cavitation method for intensification of OPW disposal by sodium hypochlorite wastes generated during the production of chlorine and caustic soda. The volume of OPW that can be neutralized by this method increases to $40-47 \%$.

Significant part of energy during cavitation excitation is transformed into heat. This leads to the increase in temperature of the water environment. Research, which data presented above, was carried out under isothermal conditions in order to confirm the effectiveness of cavitation use even at low temperatures $(293 \pm 1 \mathrm{~K})$. Further studies were performed under conditions close to adiabatic ones at $n\left(\mathrm{O}_{2, \mathrm{NaClO}}\right): n\left(\mathrm{O}_{2, \mathrm{org}}\right)=$ $=0.64 \mathrm{~mol} / \mathrm{mol}$ with the aim of using heat, released during cavitation, for acceleration of chemical reactions in the system.

Temperature of OPW $\left(200 \mathrm{~cm}^{3}\right)$ placed in a thermal insulated glass, increased by 18-20 degrees at ultrasound radiation intensity of $8.2 \cdot 10^{-2} \mathrm{~W} \cdot \mathrm{cm}^{-3}$ for $30 \mathrm{~min}$. The rate of organic compounds conversion was equal to $0.55 \cdot 10^{-4} \mathrm{~mol} /\left(\mathrm{s} \cdot \mathrm{dm}^{3}\right)$ within the first $10 \mathrm{~min}$ when temperature rose by 6.5 degrees, i.e. it increased only by $8 \%$ comparing to isothermal conditions. Accordingly, the temperature coefficient was equal to 1.12 , which is typical for diffusion area of the process. Oxidation rate of organic compounds increased during the next two 10-minute periods of the process by 17 and $32 \%$ comparing with the same period of the isothermal process. The temperature increase during every mentioned period was 6.5-7 degrees.

The value of temperature coefficient for the specified time of study is equal to $1.12-1.28$ and is characteristic for diffusion region. This can be explained by the highest rate interaction of organic compounds with sodium hypochlorite in the cavitation area localized under the magnetic enhancer of magnetostrictor (Fig. 6). Most possibly, the rate of the process is limited by the organic compounds flow into the cavitation area.

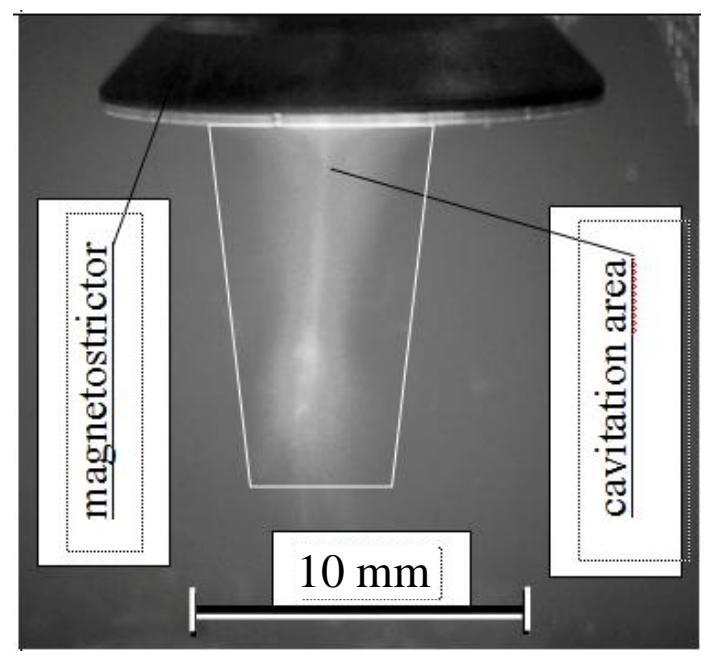

Fig. 6. The cavitation area under magnetostrictor (photo was made through an orange light filter)

It was established, that duration of the process (to achieve sustainable ORP value) for $n\left(\mathrm{O}_{2, \mathrm{NaClO}}\right): n\left(\mathrm{O}_{2, \text { org }}\right)$ $\approx 0.64 \mathrm{~mol} / \mathrm{mol}$ under adiabatic conditions is $23-27 \%$ lower in comparison with isothermal ones. COD value of the environment after finishing the process is 40 $60 \mathrm{mgO}^{2} / \mathrm{dm}^{3}$, at least 2.5 times less than under isothermal conditions. COD value, which was achieved under adiabatic conditions, allows dumping sewage or liquid wastes even into natural water reservoirs.

\section{Conclusions}

1. Oxidation of aromatic organic compounds by sodium hypochlorite to stable end products $\left(\mathrm{CO}_{2}\right.$ and $\mathrm{H}_{2} \mathrm{O}$ ) occurs through the stage of oxidative degradation.

2. The duration of the interaction of sodium hypochlorite with organic compounds in liquid wastes is determined by the reactants ratio to achieve the sustainable ORP value: the largest interaction time is observed at the ratio close to equimolar one due to the sharp decrease of the process rate at its final stages.

3. Implementation of the process in the cavitation field allows to reach the equivalence point for the sodium hypochlorite/organic compounds ratio 2.36 and 3.0 times less in comparison with the theoretically calculated ratio and experimentally determined without cavitation, respectively. Thus rate of interaction between these compounds increases by more than 6 times. This is due to parallel processes of cavitation degradation of organic compounds, sonolysis of water with the formation of intermediate compounds of oxidative character and fuller use of sodium hypochlorite as the oxidant.

4. It was established that in case of interaction between sodium hypochlorite and organic compounds as 
components of liquid wastes in the cavitation field, formed by magnetostrictive ultrasonic emitter, the process occurs in the diffusion area.

5. Implementation of the process in the cavitation field under adiabatic conditions allows to intensify significantly the interaction between organic compounds and sodium hypochlorite due to increasing medium temperature during cavitation.

6. The obtained results confirm the effective disposal of olefin liquid wastes by sodium hypochlorite solutions, particularly in case of cavitation.

\section{References}

[1] Vasilenko L., Nikiforov A., Lobuhina T.: Metody Ochistki Promyshlennyh Stochnyh Vod. Ural. Gos. Lesotechn. Univ., Ekaterinburh 2009.

[2] Malyovanyy M., Sakalova G., Chornomaz N., Nahurskyy O.: Chem. Chem. Technol., 2013, 7, 191.

[3] Mackenzie D.: Water and Wastewater Engineering. McGrawHill, New York, Madrid, New Delhi 2010.

[4] Zapol'skyy A.: Vodopostachannia, Vodovidvedennia ta Iakist' Vody. Vyscha schola, Kyiv 2005.

[5] Mason T., Tiehm A.: Advances in Sonochemistry, v.6, $1^{\text {st }}$ edn. Elsevier 2001.

[6] Yuequn T., Jun C., Xiulan H. et al.: Chem. Eng. Technol., 2016, 39, 1363. https://doi.org/10.1002/ceat.201500362

[7] Dular M., Griessler-Bulc T., Gutierrez-Aguirre I. et al.:

Ultrason. Sonochem., 2016, 29, 577.

https://doi.org/10.1016/j.ultsonch.2015.10.010.

[8] Koval I., Kislenko V., Shevchuk I., Starchevskyy V.: Chem. Chem. Technol., 2011, 5, 463.
[9] Shabarov Yu.: Organicheskaia Khimiia, Tom 1. Khimiia, Moskva 1994.

[10] Fiodorova E.: Instrumentalnye Metody Analiza

Organicheskikh Veschestv. Sykt. lesn. inst., Syktyvkar 2013.

[11] Roberts Dzh., Kaserio M.: Osnovy Organicheskoi Khimii, Tom 1. Mir, Moskva 1978.

[12] Margulis M.: Zvukokhimicheskie Reaktsii i

Sonolyuminestsentsiia. Khimiia, Moskva 1986.

Received: February 06, 2017 / Revised: February 27, 2017 /

Accepted: April 25, 2017

\section{ДОСЛІДЖЕННЯ ПРОЦЕСУ ЗНЕШКОДЖЕННЯ РІДКИХ ВІДХОДІВ ВИРОБНИЦТВА ОЛЕФІНІВ РОЗЧИНАМИ НАТРІЮ ГІПОХЛОРИТУ}

Анотація. Досліджено вплив співвідношення органічних сполук алкенового та аренового рядів як компонентів стічних вод виробництва олефінів, загальний вміст яких виражений величиною хімічного спожсивання кисню, з натрію гіпохлоритом як рідким відходом виробництва каустичної соди $i$ хлору. Встановлено принципову можливість взаємного знешкодження рідких відходів та стічних вод. Здійснення прочесу в кавітаційному полі дає змогу істотно скоротити тривалість процесу та зменшити співвідношення між натрію гіпохлоритом та органічними сполуками. Реалізачія иього прочесу в адіабатичних умовах збільшує швидкість прочесу внаслідок збільшення температури середовища завдяки явищу кавітаціiі. 3а розрахованими кінетичними параметрами процесу встановлено, щчо у разі збудження кавітації за допомогою магнітострикиійного випромінювача прочес відбувається у дифузійній області.

Ключові слова: знешкодження рідких відходів, очищення стічних вод, натрію гіпохлорит, кавітація, алкени, арени, деструкиія. 